\title{
Migration behaviour of fluoride in contaminated soils near ammophos production plant: laboratory studies
}

\section{Andrey Litvinovich ${ }^{1}$, Olga Pavlova ${ }^{1}$, Anton Lavrishchev ${ }^{2}$, Vladimir Bure ${ }^{1,3}$, and Elmira Saljnikov ${ }^{4,5}$}

${ }^{1}$ Agrophysical Research Institute, Grazhdanskii Ave., 14, Saint Petersburg, 195220, Russian Federation

${ }^{2}$ Saint Petersburg State Agrarian University, Peterburgskoe Road, 2, Saint Petersburg, 196601, Russian Federation

${ }^{3}$ Saint Petersburg State University, Universitetskaya nab., 7-9, Saint Petersburg, 199034, Russian Federation

${ }^{4}$ Soil Science Institute, Teodora Drajzera 7, Belgrade, 11000, Serbia

${ }^{5}$ Mitscherlich Akademie für Bodenfruchtbarkeit (MITAK), GmbH, 14641, Paulinenaue, Prof.-Mitscherlich-Alle 1, Germany

Address correspondence and requests for materials to Anton Lavrishchev, av.lavrishchev@yandex.ru

\section{Abstract}

Fluoride contamination of irrigated alkaline soils (Irragric Anthrosols) is a common problem in the areas of vast cotton production in Uzbekistan. Large number of laboratory measurements using corresponding models allows deeper studying the fluoride mobility in contaminated soil in the vicinity of Ammophos production factory. In a series of column experiments the migration ability of fluoride was studied in Irragric Anthrosols of different particle size distribution and four different experiments using near neutral and acidic washing water in the low, moderate and highly contaminated soils. It has been established that studied soils, located in the zone of airborne emissions from the Ammophos production plants, have a weak fluoride-holding capacity. The intensity of fluoride migration was conditioned by the initial level of soil contamination. Repeated simulated irrigation of the soil didn't result in complete removal of fluoride. At low contamination level (3.5 mg F/kg soil) on sandy-loam soil, concentration of fluoride increased with increasing of the volume of leaching moisture. With medium contamination level $(6.1 \mathrm{mg} \mathrm{F} / \mathrm{kg}$ soil) on a loamy soil, the average leaching rate was near zero throughout the measurement interval. At high contamination level $(17.5 \mathrm{mg} / \mathrm{kg})$ on heavy textured soil, the increase in the concentration of fluoride in the eluates was observed throughout the entire study interval and posed a threat of ground water contamination.

Keywords: soil contamination, fluoride, migration, irrigation, modelling.

\section{Introduction}

Fluoride is considered a toxic element for plants and animals if found in soils in high concentrations (Rezaei et al., 2017).The main anthropogenic sources of soil pollution by fluoride are plants for the production of aluminum and steel, phosphate fertilizers, and cement and brick factories. Agronomic practices such as irrigation and application of fertilizer also lead to high fluoride content in soil (Brindha et al., 2011), which results in fluoride entering aquifers through natural leaching processes.

Previous studies established that once in the soil, fluoride is quite quickly fixed by the soil absorbing complex. It has been found that the $\mathrm{pH}$ and grain size of the soil, initial fluoride concentration in clay minerals, and salinity are the factors responsible for the adsorption-desorption process of fluoride in clay minerals (Huangand Jackson, 1965; Bower and Hatcher, 1967; Marion, Henricks, 
Dutt and Fuller, 1976; Dubrovina and Kornblum, 1984; Sivasankar et al., 2016; Murugesh et al., 2016). Ilkun and Mutruk (1976) showed that with an increase in the content of silt and colloidal fractions, the ability of soils to retain fluoride rapidly increased. In the experiments of Huang and Jackson (1965), quartz turned out to be practically inert to the action of fluoride potassium (KF), indicating that fluoride-retaining capacity depends on the grain size and chemical composition of the soil.

To date, the literature has sufficiently covered fluoride behaviour in the soil-plant system (Pickering, 1985; Elrashidi and Lindsay, 1986; Semendyaeva et al., 1988; Litvinovich et al., 2001; Litvinovich and Pavlova, 2002; Mirlean and Roisenberg, 2007; Jha et al., 2009; Mourad et al., 2009; Tayibi et al., 2009; Pérez-López et al., 2010; Smidt et al., 2011; Lakshmi et al., 2016; Savenko and Savenko, 2019). However, insufficient research has been done on fluoride migration in alkaline soil (Ilkun and Motruk, 1976; Litvinovich et al., 1999; Poulsen, 2011), and publications on mathematical modelling of fluoride migration are scarce (Frid and Borisochkina, 2019).

Savasankar et al. (2016) reported that at elevated alkalinity, the presence of $\mathrm{OH}$ sites in biotite, mica, clay, and similar other minerals is most likely to be replaced with $\mathrm{F}$, and their further dissolution might result in remarkable fluoride concentrations in water sources. Kabata-Pendias and Mukherjee (2007) found that in calcium-rich soils, fluoride reacts with calcium and forms the poorly soluble compound $\mathrm{CaF}_{2}$ (fluorite); therefore, the calcium geochemical barrier is important for intra-and inter-soil migration of fluoride (Rezaei et al., 2017). Another group of authors reported that alkaline soils have a weak ability to retain fluoride (Kudzin and Pashova, 1970).

The territory of Uzbekistan is one of the biggest world cotton production areas, where cotton is mostly grown on alkaline Irragric Anthrosols soil (WRB, 2015). Cotton grown on calcareous and alkaline soils is repeatedly fertilized and irrigated (Abdullaev et al., 2007; Djanibekov et al., 2010), which causes certain chemical and mechanical changes in the behavior of fluoride in contaminated soils. Kabata-Pendias and Mukherjee (2007) found that fluoride from artificial sources is easily soluble, but the majority of it quickly disappears from a soil solution due to bonding to some soil components such as clay, $\mathrm{Ca}, \mathrm{P}$ and $\mathrm{Al}$, or due to the leaching process in sandy soils.

The goals of this research included studying the effect of technogenic contamination of Irragric Anthrosols with water-soluble fluoride and its migration under repeated soil washing with different initial contamination levels and with different soil textures; to determine the intensity of fluoride leaching at different $\mathrm{pH}$ levels of irrigation waters; to establish the average rate of change in the concentration of fluoride; to develop empirical models describing the fluoride leaching process from irrigated soils of different levels of contamination.

\section{Materials and Methods}

Soils from three different locations were sampled from the zones of airborne emissions from two large ammophos production plants located in Uzbekistan. The soils were brought to the laboratory of the Agrophysical Research Institute in St. Petersburg, Russia, where a series of column experiments were set up. The sampled soils from the cotton field differed in particle size distribution and the level of contamination with fluoride. Soils with different granulometric composition and level of fluorine contamination were deliberately selected for research in order to determine the impact of these factors on the migration ability of fluorine.

During the growing season cotton fields are irrigated six to eight times with the amount of water that allows soaking one meter of soil depth (Abdullaev et al., 2007), which provides multiple percolation of the arable layer during one cotton growing season. In our experiments six to eight washings were carried out to study the intensity of fluorine migration.

The first site was located in West Fergana, in the city of Kokand, $3.5 \mathrm{~km}$ from an ammophos factory that has been operating since 1983. Soil was sampled from the 0-25 cm layer. At the time of soil sampling, 8655 tons of fluoride compounds were released into the atmosphere in 7 years (1983-1990). The soil was sandy loam; fluoride content was $3.56 \mathrm{mg} / \mathrm{kg}$ of soil weight. Chemical composition of the soil is given in Table 1. Soil from this site was used to study the effect of the acidity of washwater on the migration of fluoride in two experiments: with deionized water ( $\mathrm{pH}$ 6.2) (Experiments No. 1, 3 and 4) and with water with $\mathrm{pH} 3.5$ (Experiment No. 2). In the second experiment, the $\mathrm{pH}$ level of the atmospheric precipitation near the site was simulated. To achieve the desired $\mathrm{pH}$, deionized water was acidified with $\mathrm{H}_{2} \mathrm{SO}_{4}$. The water used in experiments didn't contain fluorine. The $\mathrm{pH}$ was determined in each eluate.

The second site was located directly on the industrial sites of the Samarkand chemical plant. The soil was light loam; fluoride content was $6.1 \mathrm{mg} / \mathrm{kg}$ of soil weight. Soils from Sites 2 and 3 were used to establish the scale of migration of fluoride from loamy soils of various levels of pollution (Experiment No. 3).

The third site was located in the Samarkand Oasis, which occupies the third level terrace of the middle part of the Zeravshan River, $0.6 \mathrm{~km}$ from the pollution source. The Samarkand chemical plant started its operation in 1954, producing superphosphate. Later in 1977 it was converted to the production of ammophos. At the time of soil sampling, according to the factory sanitary laboratory, 34472.6 tons of fluoride compounds were re- 
Table 1. Chemical composition of Irragric Anthrosols (Sierozem-oasis soils), \%

\begin{tabular}{|c|c|c|c|c|c|c|c|c|c|c|c|}
\hline $\begin{array}{c}\text { Particles < } \\
0.01 \mathrm{~mm}\end{array}$ & Humus & $\mathrm{pH}_{\mathrm{H} 2 \mathrm{O}}$ & $\mathrm{SiO}_{2}$ & $\mathrm{Al}_{2} \mathrm{O}_{3}$ & $\mathrm{Fe}_{2} \mathrm{O}_{3}$ & $\mathrm{CaO}$ & MgO & $\mathrm{K}_{2} \mathrm{O}$ & $\mathrm{MnO}$ & $\mathrm{Na}_{2} \mathrm{O}$ & $\mathrm{P}_{2} \mathrm{O}_{5}$ \\
\hline \multicolumn{12}{|c|}{ Sandy-loam soil, $3.5 \mathrm{~km}$ from the Novo-Kokand chemical plant } \\
\hline 15.7 & $\begin{array}{c}0.90 \pm \\
0.1\end{array}$ & 8.1 & $\begin{array}{c}57.50 \pm \\
2.5\end{array}$ & $\begin{array}{c}10.90 \pm \\
0.6\end{array}$ & $\begin{array}{c}4.61 \pm \\
0.1\end{array}$ & $\begin{array}{c}9.53 \pm \\
1.1\end{array}$ & $\begin{array}{c}2.51 \pm \\
0.2\end{array}$ & $\begin{array}{c}1.80 \pm \\
0.1\end{array}$ & $\begin{array}{c}0.07 \pm \\
0.01\end{array}$ & $\begin{array}{c}1.72 \pm \\
0.3\end{array}$ & $\begin{array}{c}0.24 \pm \\
0.02\end{array}$ \\
\hline \multicolumn{12}{|c|}{ Light-loam soil, the industrial territory of Samarkand chemical plant } \\
\hline 25.5 & $\begin{array}{c}1.00 \pm \\
0.2\end{array}$ & 8.0 & $\begin{array}{c}54.57 \pm \\
3.6\end{array}$ & $\begin{array}{c}12.19 \pm \\
0.5\end{array}$ & $\begin{array}{c}5.03 \pm \\
0.3\end{array}$ & $\begin{array}{l}9.5 \pm \\
1.4\end{array}$ & $\begin{array}{c}2.7 \pm \\
0.3\end{array}$ & $\begin{array}{c}1.92 \pm \\
0.2\end{array}$ & $\begin{array}{c}0.08 \pm \\
0.01\end{array}$ & $\begin{array}{c}1.8 \pm \\
0.4\end{array}$ & $\begin{array}{l}0.23 \pm \\
0.05\end{array}$ \\
\hline \multicolumn{12}{|c|}{ Heavy-loam soil, $0.6 \mathrm{~km}$ from the Samarkand chemical plant } \\
\hline 50.4 & $\begin{array}{c}1.05 \pm \\
0.1\end{array}$ & 7.8 & $\begin{array}{c}57.02 \pm \\
1.5\end{array}$ & $\begin{array}{c}11.36 \pm \\
0.4\end{array}$ & $\begin{array}{c}4.57 \pm \\
0.4\end{array}$ & $\begin{array}{c}8.67 \pm \\
1.0\end{array}$ & $\begin{array}{c}3.13 \pm \\
0.1\end{array}$ & $\begin{array}{c}1.85 \pm \\
0.3\end{array}$ & $\begin{array}{c}0.06 \pm \\
0.01\end{array}$ & $\begin{array}{c}1.72 \pm \\
0.4\end{array}$ & $\begin{array}{l}0.23 \pm \\
0.05\end{array}$ \\
\hline
\end{tabular}

Table 2. Fluorine concentration in the eluates of studied soils, $\mathrm{mg} / \mathrm{dm}^{3}$

\begin{tabular}{|c|c|c|c|c|}
\hline \multirow{4}{*}{$\begin{array}{c}\text { Washing } \\
\text { terms }\end{array}$} & \multicolumn{4}{|c|}{ Soil, no. experiment } \\
\hline & \multicolumn{2}{|c|}{$\begin{array}{c}\text { Arable } \\
\text { sandy-loam soil }\end{array}$} & \multirow{2}{*}{$\begin{array}{l}\text { Light-loam from } \\
\text { industrial zone }\end{array}$} & \multirow{2}{*}{$\begin{array}{c}\text { Arable } \\
\text { heavy-loam }\end{array}$} \\
\hline & Irrigated with water $\mathrm{pH} 6.2$ & Irrigated with water $\mathrm{pH} 3.5$ & & \\
\hline & Experiment no 1 & Experiment no 2 & Experiment no 3 & Experiment no 4 \\
\hline 1 & $\frac{3.90 \mathrm{a} t \pm 0.21}{0.49 a}$ & $\frac{4.98 b \pm 0.31}{0.62 b}$ & $\frac{4.99 b \pm 0.29}{0.62 b}$ & $\frac{7.84 c \pm 0.34}{0.98 c}$ \\
\hline 2 & $\frac{3.68 a \pm 0.15}{0.46 a}$ & $\frac{4.39 b \pm 0.25}{0.55 a}$ & $\frac{6.89 c \pm 0.39}{0.86 b}$ & $\frac{18.53 d \pm 0.55}{2.32 c}$ \\
\hline 3 & $\frac{3.68 a \pm 0.16}{0.46 a}$ & $\frac{3.92 a \pm 0.26}{0.49 a}$ & $\frac{9.26 b \pm 0.41}{1.16 b}$ & $\frac{19.95 c \pm 0.59}{2.49 c}$ \\
\hline 4 & $\frac{3.44 a \pm 0.18}{0.43 a}$ & $\frac{3.92 a \pm 0.27}{0.49 a}$ & $\frac{11.64 b \pm 0.50}{1.46 b}$ & $\frac{18.53 c \pm 0.45}{2.32 c}$ \\
\hline 5 & $\frac{3.87 a \pm 0,22}{0.48 a}$ & $\frac{3.84 a \pm 0.22}{0.48 a}$ & $\frac{8.08 b \pm 0.40}{1.01 b}$ & $\frac{17.58 c \pm 0.41}{2.20 c}$ \\
\hline 6 & $\frac{4.28 a \pm 0.29}{0.54 a}$ & $\frac{3.92 a \pm 0.26}{0.49 a}$ & $\frac{7.83 b \pm 0.35}{0.98 b}$ & $\frac{28.03 c \pm 0.65}{3.50 c}$ \\
\hline 7 & $\frac{3.33 a \pm 0.30}{0.42 a}$ & $\frac{3.92 a \pm 0.21}{0.49 a}$ & $\frac{6.89 b \pm 0.31}{0.86 b}$ & $\underline{\text { nd }}$ \\
\hline 8 & $\frac{2.09 a \pm 0.20}{0.26 a}$ & $\frac{2,19 a \pm 0,15}{0.27 a}$ & $\frac{5.94 b \pm 0.24}{0.74 b}$ & $\underline{\text { nd }}$ \\
\hline Sum, mg & 3.52 & 3.88 & 7.69 & 13.81 \\
\hline $\mathrm{LSD}_{05}$ & 1.40 & 1.30 & 2.15 & 2.55 \\
\hline
\end{tabular}

Note: number above line is the concentration of fluoride in the leaked moisture, $\mathrm{mg} / \mathrm{l}$; under line is the amount of leaked fluoride, mg t different letters within a row signify statistically significant difference

leased into the atmosphere in 36 years (1954-1990). Soil was sampled from the $0-25 \mathrm{~cm}$ layer. The texture of the soil was heavy loam; fluoride content was $17.5 \mathrm{mg} / \mathrm{kg}$ of soil weight. The soil from this site was used for Experiment No. 4 to study the migration ability of fluoride in heavy textured soil.

All studied soils were alkaline with a high content of calcium.

In the laboratory experiments, $300 \mathrm{~g}$ of air-dried soil was first crushed and sieved through a 1-mm mesh soil, then placed in separatory funnels. The height of the soil was $17 \mathrm{~mm}$; the packing density was $1.0-1.1 \mathrm{~g} / \mathrm{cm}^{3}$.

To determine the extent and nature of fluoride migration, eight washings were carried out in four replications in every experiment.The total volume of leaked moisture of one funnel was 2.0 litres $(125 \mathrm{ml}$ for each wash). The eluates were collected after each washing of the soil, followed by determination offluoridecontent.

The concentration of water-soluble fluoride in the soils and wash waters was established using a fluorose- 


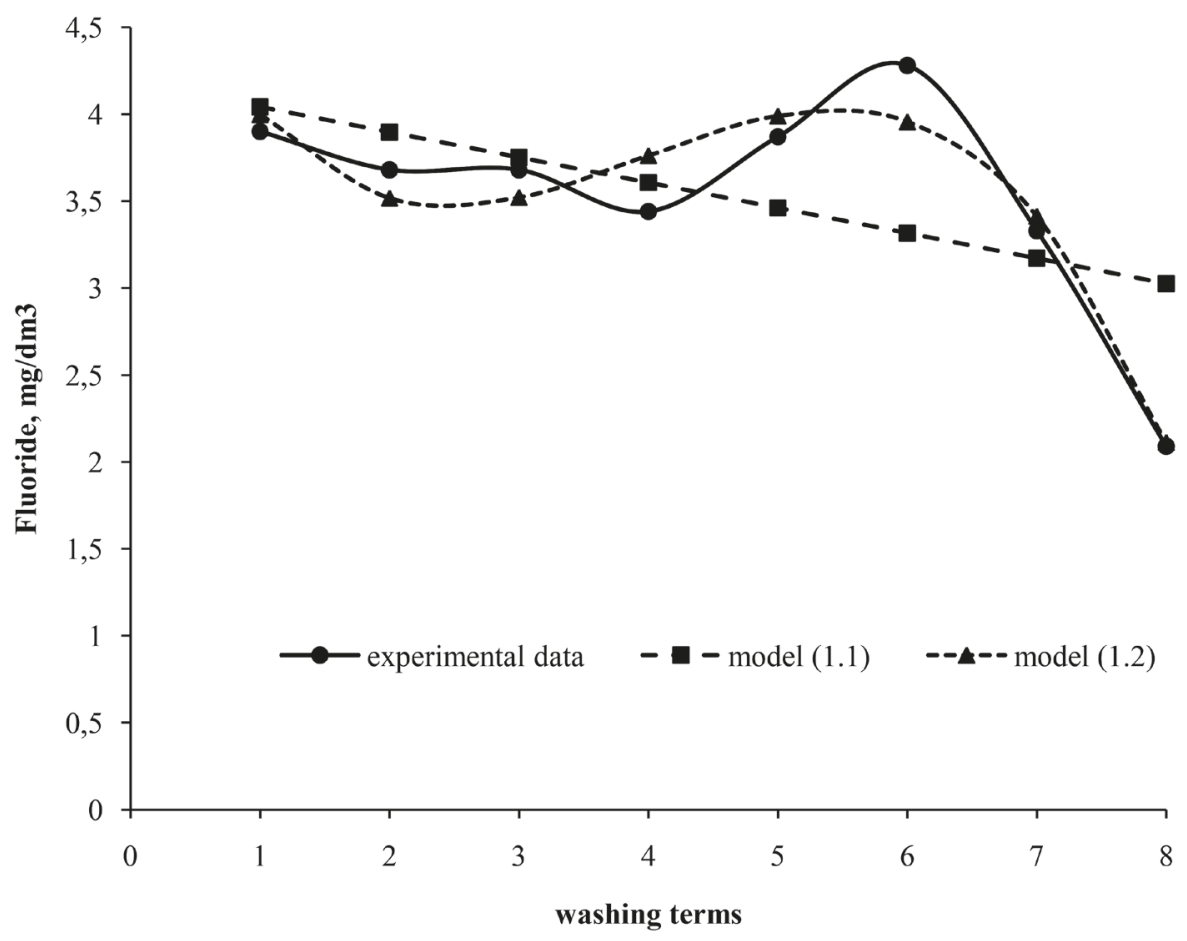

Fig. 1. Dynamics of fluoride concentration in the eluates from washwater of $\mathrm{pH} 6.2$.

lective electrode. The $\mathrm{pH}$ was established by the potentiomertric method, humus by the I. V. Tyurin method, granulometric composition by the N.A. Kachinsky method and total chemical composition by the fusion method (Samofalova and Rogiznaya, 2013). The dynamics of fluoride content in the eluates were statistically processed by regression analysis (Bure, 2007).

\section{Results}

\subsection{EXPERIMENT No. 1}

In this experiment fluoride concentration in the first eluate was already $3.9 \mathrm{mg} / \mathrm{l}$, which is 2.6 times higher than the maximum allowed concentration (MAC) level established for drinking water (1.5 mg/litre) (WHO, 2004) (Table 2). A gradual but not significant increase in fluoride concentration continued until the sixth washing, where it was $4.28 \mathrm{mg} / \mathrm{l}$, and thenits concentration gradually decreased. It is important to emphasize that in all eluates the concentration of fluoride was higher than the MAC.

A linear model of the dynamics of changes in the fluoride concentration in washwater with a starting $\mathrm{pH}$ of 6.2 was:

$$
y_{1.1}=4.19-0.145 \cdot t
$$

where $t-$ terms (conditional time). The average rate of the dynamic of fluoride change in the whole observation interval was $v_{1}=-0.145 \mathrm{mg} / \mathrm{dm}^{3}$. The model is significant at $16.5 \%(\mathrm{~F}=2.53$ at critical value $\mathrm{F}(0.835 ; 1.6)=2.499)$ and $R^{2}=0.296$ (Fig. 1).
The model of the dynamics of changes of fluoride concentration based on the polynomial of third degree is:

$$
y_{1.2}=5.2-1.66 \cdot t+0.49 \cdot t^{2}-0.04 \cdot t^{3},
$$

where $t$ - terms. Model 1.2 is significant at $1.8 \%(\mathrm{~F}=12.3$ at critical value $\mathrm{F}(0.982 ; 3.4)=12.04)$ and $R^{2}=0.90$ (Fig. 1). Model 1.1 describes the trend of the dynamics of fluoride changes, while Model 1.2 is highly significant and well describes the process.

\subsection{EXPERIMENT No. 2}

When the washwater was acidified to $\mathrm{pH} 3.5$ (Experiment No. 2) the maximum concentration of fluoride in the eluate was established in the first eluate $(4.98 \mathrm{mg} / \mathrm{l})$. After the third washing it stabilized at a level of 3.8$3.9 \mathrm{mg} / \mathrm{l}$. A decrease in concentration occurred in the eighth washing $(2.19 \mathrm{mg} / \mathrm{l})$.

Over the entire observation period, $3.88 \mathrm{mg}$ of fluoride was removed from the soil as a result of washing, i.e., 1.1 times more than when the soil was washed with distilled water with a $\mathrm{pH}$ of 6.2. The concentration of fluoride in eluates throughout the study interval exceeded the MAC, indicating that using acidified washing water didn't result in full removal of fluoride from the soil.

A linear model of the dynamics of changes in fluorideconcentrations in the experiment with acidified washwater ( $\mathrm{pH}$ 3.5) was:

$$
y_{2.1}=5.06-0.26 \cdot t,
$$




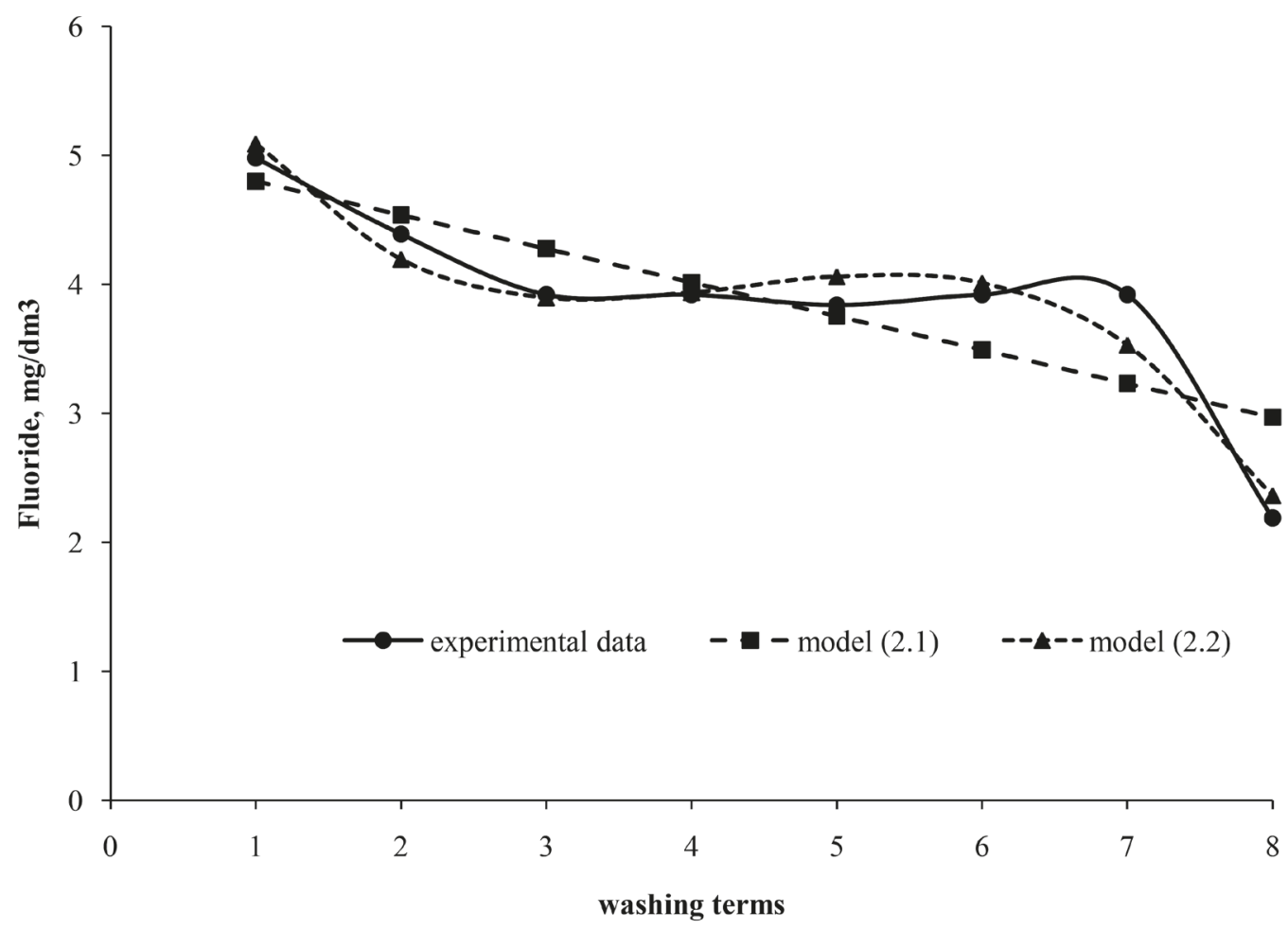

Fig. 2. Dynamics of fluoride concentration in the eluates from washwater of $\mathrm{pH} 3.5$.

The average rate of the dynamics of fluoride change in the whole observation interval was: $v_{2}=-0.26 \mathrm{mg} /$ $\mathrm{dm}^{3}$. Model 2.1 is highly significant at $2 \%(\mathrm{~F}=11.7$ at critical value $\mathrm{F}(0.98 ; 1.6)=9.876)$ and $R^{2}=0.66$ (Fig. 2 ).

The model of the dynamics of changes of fluoride concentration based on the polynomial of third degree is:

$$
y_{2.2}=6.84-2.26 \cdot t+0.55 \cdot t^{2}-0.04 \cdot t^{3},
$$

The model is significant at a very high level of $0.9 \%$ $(\mathrm{F}=18.6$ at critical value $\mathrm{F}(0.991 ; 3.4)=17.68)$ and $R^{2}=$ 0.93 (Fig. 2). Model 2.1 describes the trend of the dynamic, while Model 2.3 well describes the process.

\subsection{EXPERIMENT No. 3}

The soil from the industrial site was characterized by a higher level of contamination with fluoride compared to soils from Sites 1 and 2, which significantly influenced the scale of migration of fluorideduring the washings. With an equal volume of leaked moisture, the fluctuations in concentration of individual eluates were from 4.99 to $11.64 \mathrm{mg} / \mathrm{dm}^{3}$. This is $1.2-2.7$ times higher than its maximum content established in the eluates of the sandy loam soil.

Up to the fourth washing term, an increase was recorded in the concentration of fluoride in individual eluates, while from the fifth washing, a decrease in the concentration of fluoride was detected. Thus, we did not observe a complete removal of fluoride by leaching from the soil located on the industrial zone of the plant. This is supported by the fact that in the eighth eluate, the fluoride concentration was slightly higher than in the first. The linear model of the fluoridemigration for this experiment was:

$$
y_{3.1}=7.75-0.014 \cdot t,
$$

The average rate of the dynamics of fluoridechange in the whole observation interval was: $v_{3}=-0.014 \mathrm{mg} /$ $\mathrm{dm}^{3}$, near zero (Fig. 3). The model of the dynamics of changes of fluorideconcentration (from the factory zone) based on the polynomial of third degree was:

$$
y_{3.2}=-0.98+6.7 \cdot t-1.29 \cdot t^{2}+0.069 \cdot t^{3},
$$

Model 3.2 is significant at $7 \%(\mathrm{~F}=5.41$ at critical value $\mathrm{F}(0.93 ; 3.4)=5.32$ ) and $R^{2}=0.8$ (Fig. 3).

\subsection{EXPERIMENT No. 4}

The maximum level of fluoride contamination was found intheheavy textured soil located $0.6 \mathrm{~km}$ from the pollution source (the first eluate contained $7.84 \mathrm{mg} / \mathrm{kg}$, while the sixth contained $28.03 \mathrm{mg} / \mathrm{kg}$ ). An increase in fluoride concentration was observed as the amount of percolated moisture increased. This experiment was terminated after the sixth washing term due to silting of the columns. The total amount of leached fluoride in six washes was $13.81 \mathrm{mg}$, which is 1.8 times higher than the sum of eight washings of the soil from the industrial site. 


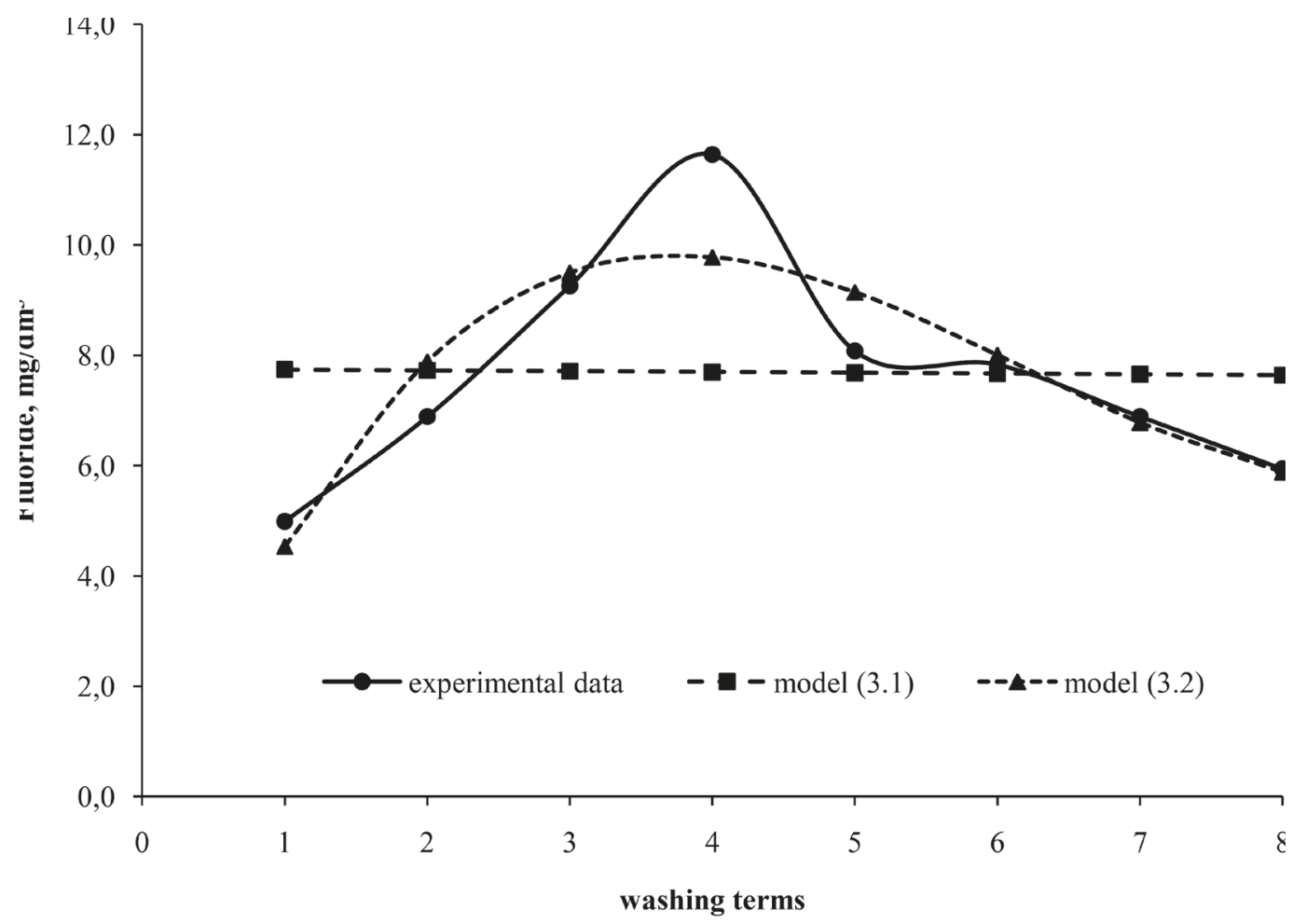

Fig. 3. Dynamics of fluoride concentration in the eluates from the experiment with a moderate level of soil contamination.

A linear model of the dynamics of fluoride concentration in the soils with a high pollution level was:

$$
y_{4.1}=8.7+2.76 \cdot t \text {, }
$$

The average rate of the dynamics of fluoride concentration in the whole observation interval was: $v_{4}=$ $2.76 \mathrm{mg} / \mathrm{dm}^{3}$. Model 4.1 is significant at $5.5 \%(\mathrm{~F}=7.23$ at critical $\mathrm{F}(0.945 ; 1.4)=7.2$ ) and $R^{2}=0.64$ (Fig. 4). The model of the fluoride dynamics in the industrial zone based on the polynomial of third degree was:

$$
y_{4.2}=-19.47+37.3 \cdot t-11.2 \cdot t^{2}+1.05 \cdot t^{3},
$$

Model 4.2 is significant at a very high level of $0.9 \%$ $(\mathrm{F}=116.3$ at critical value $\mathrm{F}(0.991 ; 3.2)=110.3)$ and $R^{2}=$ 0.994 (Fig. 4). So, the constructed empirical models are statistically significant. Model 4.1 describes the trend of the dynamic, while Model 4.2 well describes the process.

The different character of curves of fluoride concentration in the eluates was explained by different granulometric compounds of soils, levels of soil pollution and speed of the water moving in columns.

\section{Discussion}

The fluoride ion, as a strong ligand in water, forms a number of soluble complexes with polyvalent metal ions such as $\mathrm{Mg}^{2+}, \mathrm{Fe}^{3+}, \mathrm{Al}^{3+}$, and $\mathrm{Ca}^{2+}$ (Sivasankar et al., 2016) based on the $\mathrm{pH}$ of the medium. However, because in alkaline soil, where $\mathrm{Al}$ and $\mathrm{Fe}$ are in low concentrations, fluoride was unable to bind with these cations to any appreciable extent, it replaced hydroxyl sites because the ionic radius of $\mathrm{F}(1.23-1.36 \AA$ ) is close to $\mathrm{OH}$ (1.37-1.40 Å) (Sivasankar et al., 2016). Such isomorphous substitution happens when cations of comparable size, but different charge are exchanged in crystals of clay minerals (Poulsen, 2011). As $\mathrm{Ca}^{2+}$ precipitates into calcite under alkaline $\mathrm{pH}$ with abundant $\mathrm{CO}_{2}$, the dissolution of fluorite is thus enhanced, leading to fluorideenriched calcium-poor groundwater.

Ozsvath (2009) suggested that in neutral medium the insignificant binding ability of fluoride results in free fluoride ions along with minor amounts of major cation complexes and some minor and/or trace constituent complexes.

The absence of significant differences in the amount of leached fluoride between the first and second experiments (i.e., wash water with $\mathrm{pH} 6.2$ and $\mathrm{pH} 3.5$ ) is explained by the high buffering capacity of the investigated soil (Jacks et al., 2005). It was established that the $\mathrm{pH}$ of the eluate in Experiments No. 1 and No. 2 did not depend on the initial acidity of the washwater and the washing time and remained in the alkaline range $(\mathrm{pH}$ 8.2-8.6). This indicates that the initial $\mathrm{pH}$ of the percolating moisture did not significantly affect the rate of leaching of fluoride from studied alkaline soil.

Calcaric materials are often referred to as a sink for fluoride (Sivasankar et al., 2016). Kim and Jeong (2005) inferred that $\mathrm{CaF}_{2}$ dissolution is not necessarily dependent on $\mathrm{pH}$ unless it is coupled with the precipitation of 


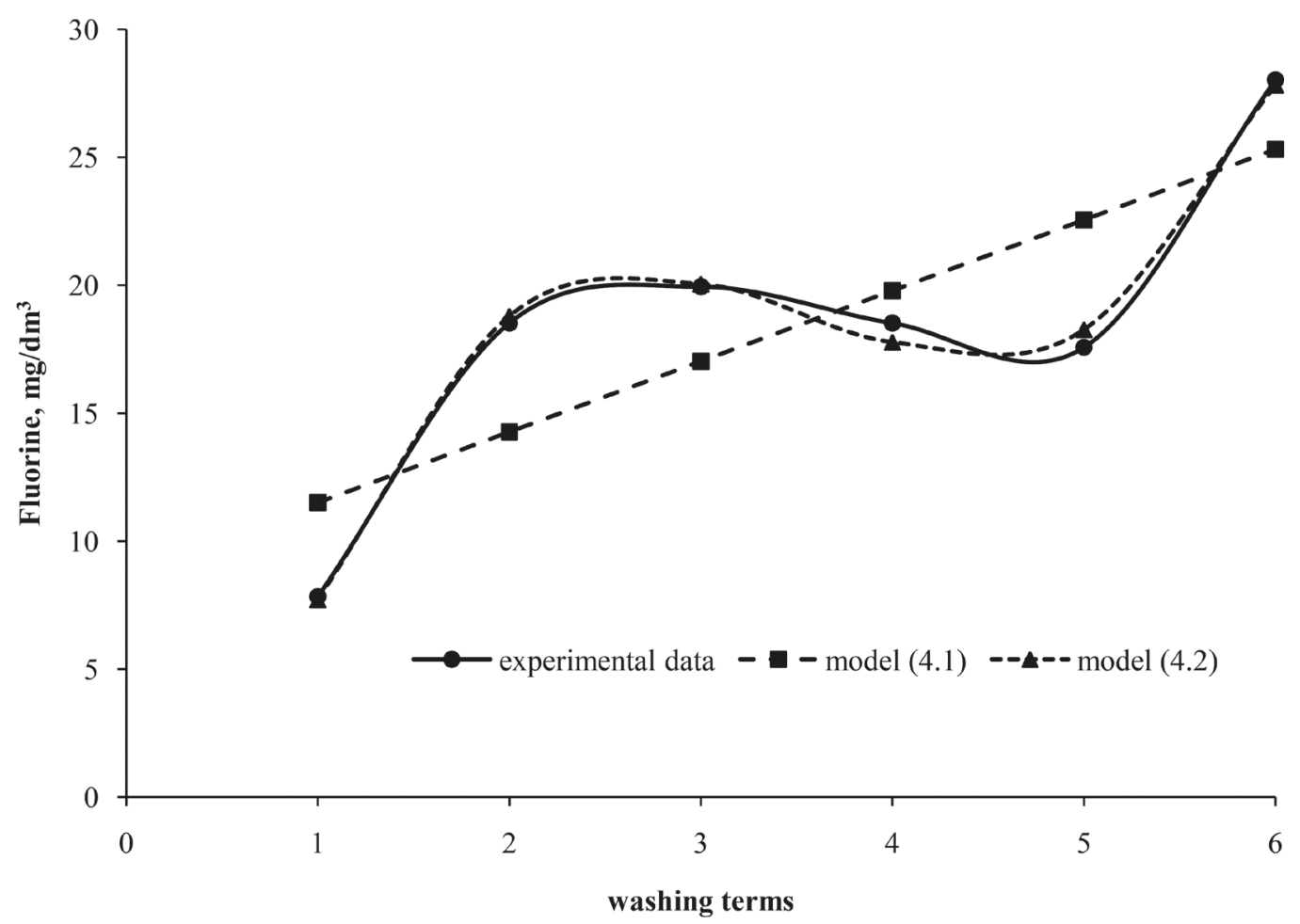

Fig. 4. Dynamics of fluoride concentration in the eluates of the experiment with highly contaminated soil.

$\mathrm{CaCO}_{3}$ by common ion effect. Probably, in our study, the precipitation of $\mathrm{CaF}_{2}$ was enhanced at high $\mathrm{pH}$ levels and thereby enabled further dissolution of fluorite in the water saturated with both $\mathrm{CaF}_{2}$ (fluorite) and $\mathrm{CaCO}_{3}$ (calcite) at the same time.

In the light loam soil the maximum concentration of fluoride was observed in the fourth washing, while in the heavy loam soil the concentration of leached fluoride increased until end of the experiment.

The higher concentrations of $\mathrm{F}$ in the eluates of the third compared to the first two experiments were due to the initially higher contamination of this soil. Also, due to the presence of finer particles more hydroxyl sites could be substituted by fluoride (Savasankar et al., 2016), forming $\mathrm{CaF}_{2}$ that eventually was dissolved in the washwater.

The above explanation also applies to the greatest fluoride concentration in the eluates of the fourth experiment. Because this soil had the greatest amount of fine particles with more capacity to absorb F, it showed significantly greater $\mathrm{F}$ concentrations in all six eluates. Moreover, judging from the increasing concentration of fluoride with washing terms in the fourth experiment, the reserves of fluoride capable of migration in the heavy textured soil remains very significant. Probably both the initial high level of contamination and the greater content of clay (i.e., increased hydroxyl sites) in this soil were responsible for unfavorable electrostatic potential or displacement of adsorbed $\mathrm{F}$ from the soil (Larsen and Widdowson, 1971).
The eluates of all experiments and washing terms showed that concentration of fluoride exceeded the MAC. The identified level of contamination suggests that if released into aquifers this may pose a threat to the health of animals and people.

The amount of leaching fluoride correlated with the amount of leaching water. This was also confirmed by Jadewsz (1976), who detected the penetration of volatile emissions from phosphate fertilizer plants to a soil depth of four to eight meters and into the groundwater.

Sivasankar et al. (2016) reported that the leaching rate of fluoride was associated with its mobility in different soils. Wanf et al. (2002) ranked the fluoride leaching ability of different soils as follows: drab soil $>$ sierozem $>$ black soil $>$ purplish soil $>$ red soil $>$ dark brown earth. According to the findings of Rezaei et al. (2017), ion exchange between fluorite and calcite is important in controlling fluoride concentration in water.

\section{Conclusions}

1. Irragric Anthrosols, located in a zone of industrial emission in the vicinity of an ammophos production factory, exhibited a weak ability to hold fluoride. Multiple thorough soil washing leads to the removal of water-soluble fluorine. Fluorine is found in all portions of filtrates. The intensity of fluorine leaching was little dependent on the $\mathrm{pH}$ of the washwater. Complete removal of fluoride by washing the 
soils selected for the study could not be achieved. Migration losses are greater the higher the initial level of soil pollution.

2. At a relatively low initial level of contamination of sandy loam soil with fluorine, its concentration in individual portions of the eluate is reduced. The total content of fluorine washed fluctuated slightly depending on the $\mathrm{pH}$ of seepage water, and amounted to $3.52-3.88 \mathrm{mg}$. With an average initial level of pollution in light loamy soil, the average rate of change of the concentration of fluoride in the eluates is not significantly different from zero. The amount of leached fluorine was equal to $7.69 \mathrm{mg}$. At a high level of contamination of the heavy textured soil an increase in fluorine concentration in the washwater of individual eluates was established throughout the period of study. The amount of F removed was limited by weak soil filtration capacity and amounted to $13.81 \mathrm{mg}$.

3. Empirical models have been developed that adequately describe the process of fluorine migration from Irragric Anthrosols of different levels of contamination.

\section{Acknowledgments}

Part of the research was supported by the Ministry of Education, Science and Technological Development of the Republic of Serbia (Grant no. TR 37006).

\section{References}

Abdullaev, I., Giordano, M., and Rasulov, A. 2007. Cotton in Uzbekistan; pp. 102-188 in Kandiyoti, D. (ed.). The cotton sector in Central Asia. University of London, chapter 3.

Bower, C. A. and Hatcher, T. 1967. Adsorption of fluoride by soils and minerals. Soil Science 103(3):151-154. https:// doi.org/10.1097/00010694-196703000-00001

Brindha, K., Rajesh, R., Murugan, R., and Elango, L. 2011. Fluoride contamination in groundwater in parts of Nalgonda District, Andhra Pradesh, India. Environmental Monitoring and Assessment 172:481-492. https://doi.org/10.1007/ s10661-010-1348-0

Bure, V. M. 2007. Methodology of statistical analysis of empirical data. $141 \mathrm{pp}$. Izdatelstvo Sankt-Peterburgskogo Universiteta, St. Petersburg. (In Russian)

Dubrovina, I. V. and Kornblyum, E. A. 1984. Nature of soil absorption of fluorine fertilizers and meliorants. Pochvovedenie 9:23-29. (In Russian)

Djanibekov, N., Rudenko, R., Lamers, J. P. A., and Bobojonov, I. 2010. Pros and cons of cotton production in Uzbekistan. In: Pinstrup-Andersen, P.; Cheng, F. (eds.) Food policy for developing countries: Case studies. Cornell University, New York.

Elrashidi, M. A. and Lindsay, W. L. 1986. Chemical equilibria of fluoride in soils: a theoretical development. Soil Science 141(4):274-280. https://doi.org/10.1097/00010694198604000-00004

Frid, A.S. and Borisochkina, T.I. 2019. Fluoride: Migration mobility in technogenically polluted soils. Agrokhimiya 3:65-71. (In Russian)

Jacks, G., Bhattacharya, P., Chaudhary, V., and Singh, K. P. 2005. Controls on the genesis of some high-fluoride groundwaters in India. Applied Geochemistry 20:221-228. https://doi.org/10.1016/j.apgeochem.2004.07.002

Jadewsz, D. 1976. Przemieszczanic z wiazkowfluoru w glebie. Prace z zakrezu nauk rolniczych. XLI:81-85.

Jha, S. K., Nayak, A. K., and Sharma, Y. K. 2009. Fluoride occurrence and assessment of exposure dose of fluoride in shallow aquifers of Makur, Unnao district Uttar Pradesh, India. Environmental Monitoring and Assessment 156:561566. https://doi.org/10.1007/s10661-008-0505-1

Huang, P.M. and Jackson, M. L. 1965. Mechanism of reaction of neutral fluoride solution with layer silicates and oxides of soils. Soil Science Society of America Journal 29(6):661-665. https://doi.org/10.2136/ sssaj1965.03615995002900060021x

Kabata-Pendias, A. and Mukherjee, A. B. 2007. Trace elements from soil to human. Springer-Verlag Berlin Heidelberg. https://doi.org/10.1007/978-3-540-32714-1

Kim, K. and Jeong, G.T. 2005. Factors influencing natural occurence of fluoride-rich groundwaters: a case study in the southeastern part of the Korean Peninsula. Chemosphere 58:1399-1408. https://doi.org/10.1016/j. chemosphere.2004.10.002

Kudzin, Yu. K. and Pashova, V. T. 1970. About fluoride content in soils and plants with long-term use of fertilizers. Pochvovedenie 2:74-79. (In Russian)

Lakshmi, D. V., Rao, K. J., Ramprakash, T., and Reddy, A. P. K. 2016. Monitoring of fluoride content in surface soils used for crop cultivation in Ramannapet Mandal of NaIgonda district, Telangana, India. Society for Environment and Development, (India) 11(2-4):59-67.

Larsen, S. and Widdowson, A. E. 1971. Soil fluorine. Soil Science 22:210-222. https://doi.org/10.1111/j.1365-2389.1971. tb01608.x

Litvinovich, A. V., Pavlova, O. Yu., and Lavrishchev, A. V. 2001. Accumulation of fluoride by various agricultural crops during the liming of soddy-podzolic soil with conversion chalk. Agrokhimiya 2:74-78. (In Russian)

Litvinovich, A. V. and Pavlova, O. Yu. 2002. Fluoridein the soilplant system under use of chemical reclamation and contamination of environment with technogenic emissions. Agrokhimiya 2:66-76. (In Russian)

Litvinovich, A. V., Pavlova, O. Yu., and Lavrischev, A. V. 1999. Migration of fluoridein soils of various natural and climatic regions. Agrokhimiya 6:74-81. (In Russian)

Marion, G. M., Henricks, D. M., Dutt, G. R., and Fuller, W. H. 1976. Aluminium and silica solubility in soils. Soil Science (2):76-85. https://doi.org/10.1097/00010694197602000-00003

Mirlean, N. and Roisenberg, A. 2007. Fluoride distribution in the environment along the gradient of a phosphate-fertilizer production emission (southern Brazil). Environmental Geochemistry and Health 29(3):179-187. https:// doi.org/10.1007/s10653-006-9061-1

Mourad, N. M., Sharshar, T., Elnimr, T., and Mousa, M. A. 2009. Radioactivity and fluoride contamination derived from a phosphate fertilizer plant in Egypt. Applied Radiation and Isotopes 67:1259-1268. https://doi.org/10.1016/j. apradiso.2009.02.025

Murugesh, S., Kiyoshi, O., Darchen, A., and Sivasankar, V. 2016, Chapter 7. Proposed Mechanisms on Fluoride Sorption; 223 pp., in V. Sivasankar (ed.), XIII, Springer. https://doi.org/10.1007/978-3-319-40686-2_8

Ozsvath, D. L. 2009. Fluoride and environmental health: a review. Reviews in Environmental Science and Bio/Technology 8:59-79. https://doi.org/10.1007/s11157-008-9136-9

Pérez-López, R., Nieto, J. M., Coto, I. L., Aguado, J. L., Bolivar, J. P., and Santisteban, M. 2010. Dynamics of contaminants in phosphogypsum of the fertilizer industry of 
Huelva (SW Spain): from phosphate rock ore to the environment. Applied Geochemistry 25(5):705-715. https:// doi.org/10.1016/j.apgeochem.2010.02.003

Pickering, W. F. 1985. The mobility of soluble fluoride in soils. Environmental Pollution Series $B$, Chemical and Physical 9(4):281-308. https://doi.org/10.1016/0143$148 \times(85) 90004-7$

Poulsen, R. 2011. The effect of fluoride pollution on soil microorganisms; 42 pp. 10 ECTS thesis, University of Iceland, Reykjavik.

Rezaei, M., Nikbakht, M., and Shakeri A. 2017. Geochemistry and sources of fluoride and nitrate contamination of ground water in Lar area, south Iran. Environmental Science and Pollution Research 24(18):15471-15487. https:// doi.org/10.1007/s11356-017-9108-0

Samofalova, I. A. and Rogiznaya, J. A. 2013. The practical laboratories for chemical analysis of soils: textbook. 133 pp. Perm. (In Russian)

Savenko, A. V. and Savenko, V. S. 2019. Water-soluble fluoride in soil. Agrokhimiya 3:61-64. (In Russian)

Semendyaeva, N. V. and Zheronkina, L. A. 1988. Effect of fluorideand phosphorus on the yield and chemical composi- tion of oat cultivated in solonetzes. Agrokhimiya 4:57-63. (In Russian)

Sivasankar, V., Darchen, A., Omine, K., and Sakthivel, R. 2016. Fluoride: a world ubiquitous compound, its chemistry, and ways of contamination. Chapter 2, In Surface modified carbons as scavengers for fluoride from water; 223 p in V. Sivasankar (ed.), XIII, Springer. https://doi. org/10.1007/978-3-319-40686-2_2

Smidt, G. A., Koschinsky, A., De Carvalho, L. M., Monserrat, J., and Schnug, E. 2011. Heavy metal concentrations in soils in the vicinity of a fertilizer factory in Southern Brazil. Landbauforschung 61(4):353-364.

Tayibi, H., Choura, M., Lopez, F. A., Alguacil, F. J., and LopezDelgado, A. 2009. Environmental impact and management of phosphogypsum. Journal of Environmental Management 90(8):2377-2386. https://doi.org/10.1016/j.jenvman.2009.03.007

WHO, 2004. Guidelines for drinking water quality. Reccomendations, vol 1. World Health Organization, Geneva.

WRB, 2015. World Reference Base of Soil resources. World Soil resources Reports 106 Food and Agriculture Organization of the United Nations; 192 p. Rome. Italy. 